\title{
セメント質の線維性基質と層板構造
}

\author{
松尾朗矢嶋俊彦 \\ 東日本学園大学歯学部口腔解剖学第一講座 \\ (主任 : 矢嶋俊彦教授) \\ (平成元年 9 月 29 日受付)
}

\section{Fibrous Components and Lamellar Structures in Cementum}

\author{
Akira MATSUO and Toshihiko YAJIMA \\ Department of Oral Anatomy, School of Dentistry, Higashi-Nippon-Gakuen University \\ Ishikari-Tobetsu, Hokkaido, 061-02 Japan \\ (Chief : Prof. Toshihiko YAJIMA)
}

\begin{abstract}
The purpose of this study was to clarify the relationship between the lamellar structure and the fibrous components of cementum. Freeze-fracture specimens and ground sections of the human molar cementum were treated with acid- and/or alkalinesolutions, then examined by scanning electron microscopy. Both of the layers of Sharpey (extrinsic) fiber and matrix (intrinsic) fiber were distinguished in freeze-fracture specimens and ground sections, but no lamellar structures appeared. For the first time, the lamellae isolated with narrow grooves were clearly observed on the ground sections that were treated with $5 \%$ sodium hypochlorite for $60 \mathrm{~min}$
\end{abstract}

followed by $0.5-1.0 \mathrm{M}$ hydrochloric acid for 30-60 sec. In addition to the two fiber-layer types, the mixed fiber layer containing both components of matrix and Sharpey's fibers was classified, and the lamellar arrangement of matrix fibers was also revealed. When the hypochlorite treatment time was prolonged for $120 \mathrm{~min}$, the lamellar structures were evident.

Our results show that those treatments may resolve the regions of physiological hypomineralization related to the incremental lines running parallel to the cemento dentinal junction and the lines of discontinuity of the fibrous components.

Key words : Cementum, Cement lamella, Sharpey's fiber, Matrix fiber, Scanning electron microscopy 要旨 : セメント質の線維性基質と層板構造の関係を明らかにするため, ヒト歯の凍結割断面と研磨面を酸のみ, またはアルカリと酸で処理し走査型電子顕微鏡で観察した。割断面と研磨面では, シャーピー（非固有）線維層と基 質 (固有) 線維層を区別できたが, 明瞭な層構造は認められなかった。層板構造は, 研磨面を $5 \%$ 次亜塩素酸ナト リウム溶液で 60 分間処理し，さらに 0.5 1.0 M 塩酸で $30 \sim 60$ 秒間処理すると初めて観察された。さらに，両線維 層に加え，シャーピー線維と基質線維を含む混合線維層が認められ，基質線維の層状構造も明かとなった。また，次 亜塩素酸の処理時間を 120 分間にすると，層構造がより明瞭となった。

これらの結果より，この処理がセメント-象牙境と平行している成長線であり，線維性基質の不連続である生理的 な低石灰帯に作用していることが示唆された。

索引用語 : セメント質, セメント層板, シャーピー線維, 基質線維, 走査型電子顕微鏡 


\section{緒言}

セメント質の微細構造に関しては，透過型電子顕微鏡 と走査型電子顕微鏡で多くの報告がすでになされてい る。透過型電子顕微鏡では，まずセメント質断面のレプ リカ像が観察された1,2)。さらに超薄切片により, 歯頸側 の無細胞セメント質では，セメント一象牙境に垂直で， 歯周鞋帯の主線維に連続するシャーピー線維（非固有線 維）が主な線維性基質であることが報告されている ${ }^{3 \sim 5)}$ 。 有細胞セメント質では，シャーピー線維の間に不規則に 配列する基質線維 (固有線維) が存在すること, 基質線 維にはセメント質表面と平行に走行する線維と，不規則 に配列する線維が存在することが報告されている ${ }^{4,6) 。 ~}$ さらに，基質線維束が明瞭に認められる部分では，線維 束の縦断面と横断面が交互に重なる層構造が認められて いる。そして，これらの基質線維束の間に，この基質線 維束に交差し, 連続する短い交差線維の存在が報告され ている7)。走査型電子顕微鏡では，セメント質表面構造 に関して詳細に記載され，シャーピー線維束の分布など が明らかにされている8 10)。また，セメント小腔の形態 や，割断面のシャーピー線維の配列などに関しても報告 されている11 13)。しかし，これらの報告では，セメント 質の光学顕微鏡で観察される構造とその微細構造, 特に 層板構造とそれを形成する線維性基質との関係は明らか にされていない。

そこで我々は, ヒトの歯のセメント質の構造と線維性 基質の関係を明らかにするため，走査型電子顕微鏡を用 いてセメント質断面を観察した。本実験では，セメント
質の割断面と研磨面を比較し，さらに研磨面を次亜塩素 酸ナトリウムと塩酸で処理し，層板構造と線維性基質の 関連をより明確にすることを試みた。

\section{材料と方法}

材料にはヒトの抜去臼歯を用いた。歯は，2\% glutaraldehyde-2\% paraformaldehyde $(0.1 \mathrm{M}$ phosphate buffer, pH 7.2) で 24 時間固定した。固定後，歯は歯軸と平 行にダイヤモンドディスクで切出し研磨するか，または 凍結割断を行った。凍結割断は 15\%,25\%,50\% DMSO (dimethyl sulphoxide) で各 1 時間置換後, 液体窒素で 凍結し行った。研磨試料は一部を除いて，5\% 次亜塩素 酸ナトリウム溶液 (次亜塩素酸) で $60 \sim 120$ 分間処理し た。これらの処理後，試料はすべて 0.5〜 1 M 塩酸で 30 〜60秒間処理し線維性基質を露出させた。充分に洗浄 後, $1 \% \mathrm{OsO}_{4}(0.1 \mathrm{M}$ phosphate buffer, $\mathrm{pH} 7.2)$ で 2 時間後固定し，エチルアルコールで脱水，酢酸イソアミ ルに置換し，液化二酸化炭素中で臨界点乾燥（日立製 HCP-2，東京）を行った。さらに，金をスパッタコーテ ィングし(エイコーエンジニアリング製 IB-3, 茨城), 走査型電子顕微鏡（日立製 $\mathrm{X}-650 ） て ゙$ 観察した。

\section{結果}

\section{1. 凍結割断面}

歯頸側の薄いセメント質では，歯周勒帯からの主線維 束はセメント質に埋め込まれ，シャーピー線維束となっ ていた (図 1)。根尖側の厚いセメント質最深部において

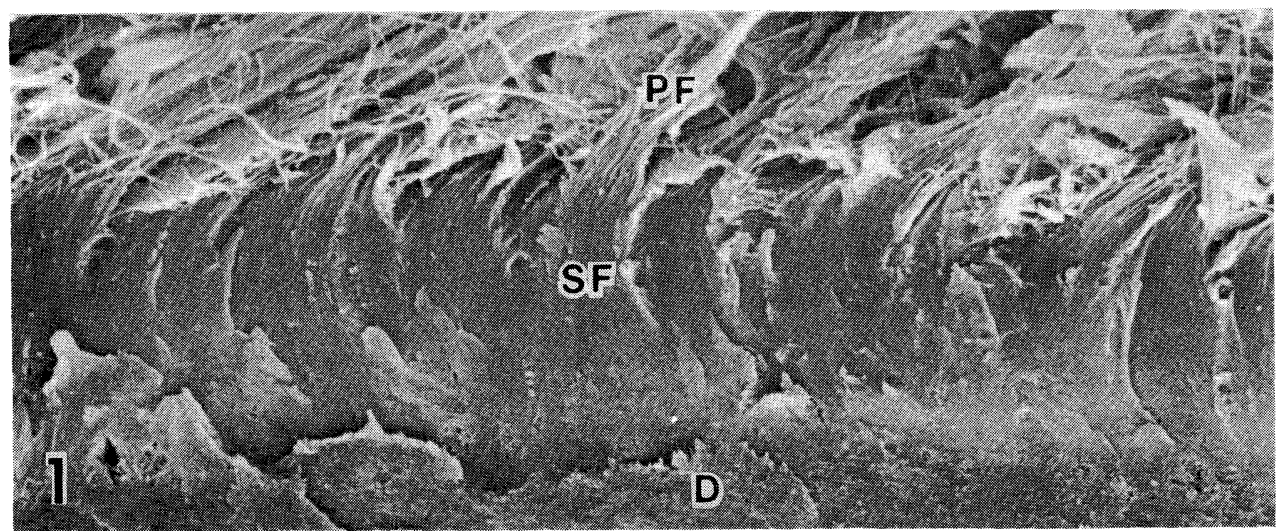

図 1 歯頸側の薄い無細胞セメント質。凍結割断, 酸処理 歯周勒带の主線維束（PF）はセメント質に埋入しシャーピー線維束 (SF) となっている。 $\mathrm{D}$ : 象牙質。 $\times 2,300$ 

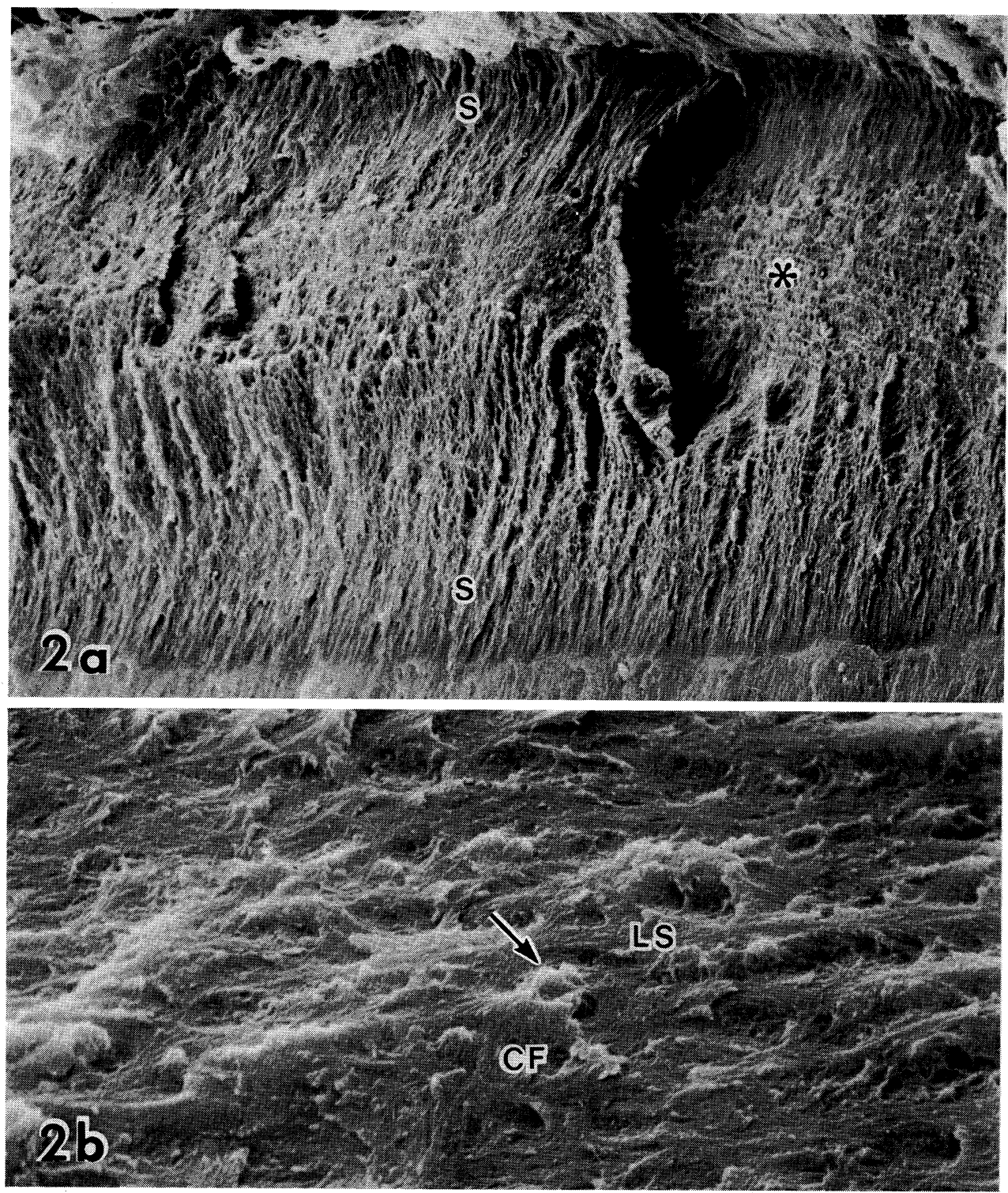

図 2 根尖側の厚いセメント質。凍結割断, 酸処理

a セメント質表層と深層のシャーピー線維層（S）に挾まれてシャーピー線維に直交する層構 造（*）が認められる。 $\times 310$

b シャーピー線維に直交する層構造（ $\mathrm{a}$ の*部分）の拡大像。セメント質表面に平行する縦断 された細い基質線維束 (LS) が層構造を形成している。この線維束に直交する交差線維 (CF) と, 横断もしくは斜断された線維束の突出（矢印）が認められる。割断面は平滑でなく, こ れらの線維相互の関係は不明瞭である。 $\times 3,100$

も，セメント一象牙境に垂直なシャーピー線維を主体と した層（シャーピー線維層）が認められた。その外側で は，セメント質表面に平行する構造が観察された（図 2 a)。この構造は, 線維束の長軸がシャーピー線維に直交
する細い基質線維束の縦断面であった（図 2 b)。また, 横断もしくは斜断された線維束の断面と, セメント質の 深部から浅部方向に走行する短い線維が認められた。し かし, 基質線維が多い部分 (基質線維層) の割断面は平 

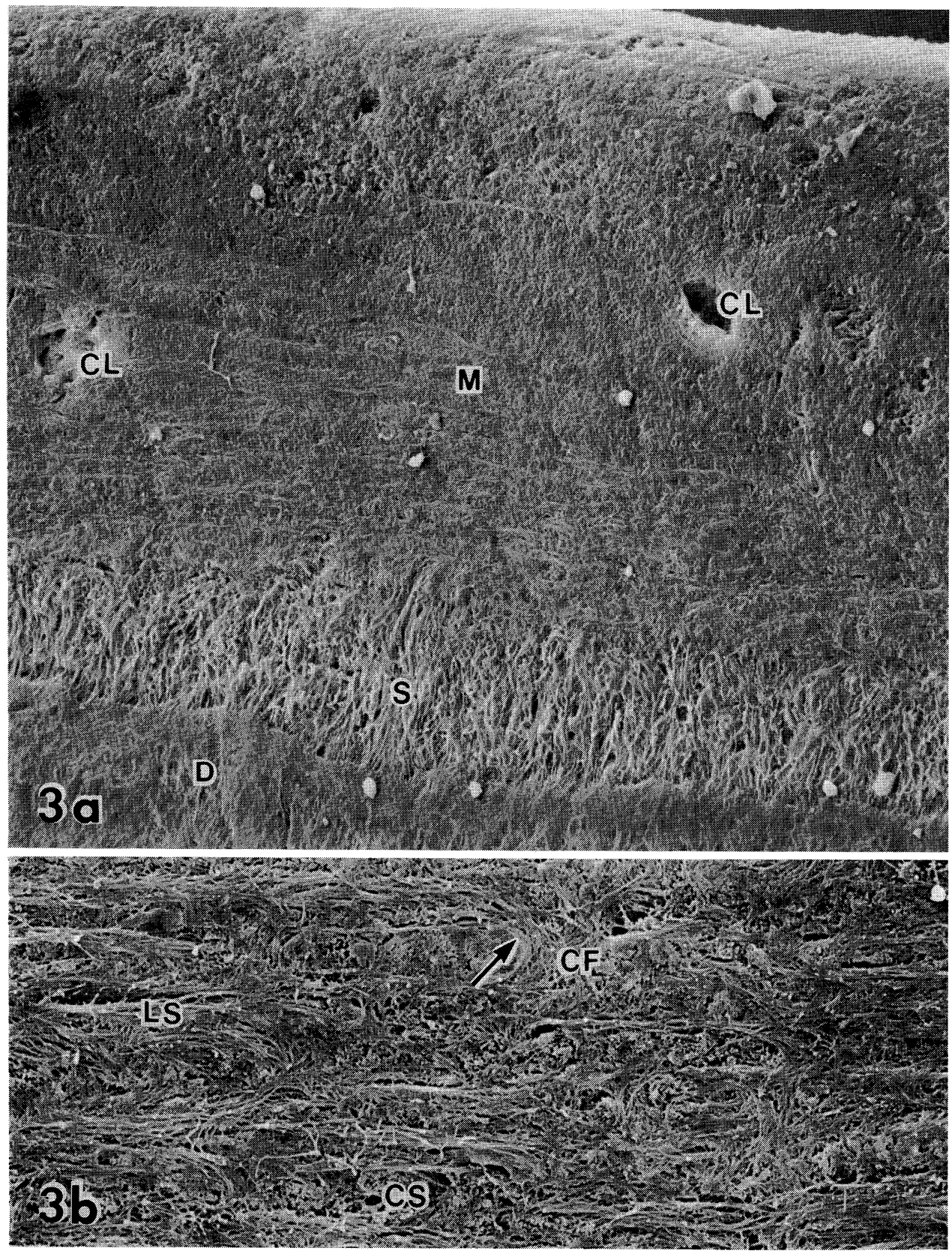

図 3 根尖側の厚い有細胞セメント質。研磨, 酸処理

a セメント質最媣部はシャーピー線維層 (S), その外層はセメント質表面まで基質線維層 (M) が認められる。光学顕微鏡で観察されるような層構造は不明瞭。CL：セメント小腔, $\mathrm{D}$ : 象牙質。 $\times 780$

b a の基質線維層の拡大像。凍結割断試料（図 $2 \mathrm{~b}$ ）と比較し基質線維が明瞭に観察される。 基質線維には歯軸方向に走行する線維束の縦断面 (LS), 歯を輪状に取巻く線維束の横断面 (CS) と，セメント質深部から浅部へ向う短い交差線維の縦断面 (CF) が認められる。交差 線維と歯軸方向の線維束は連絡している (矢印)。 $\times 2,600$ 


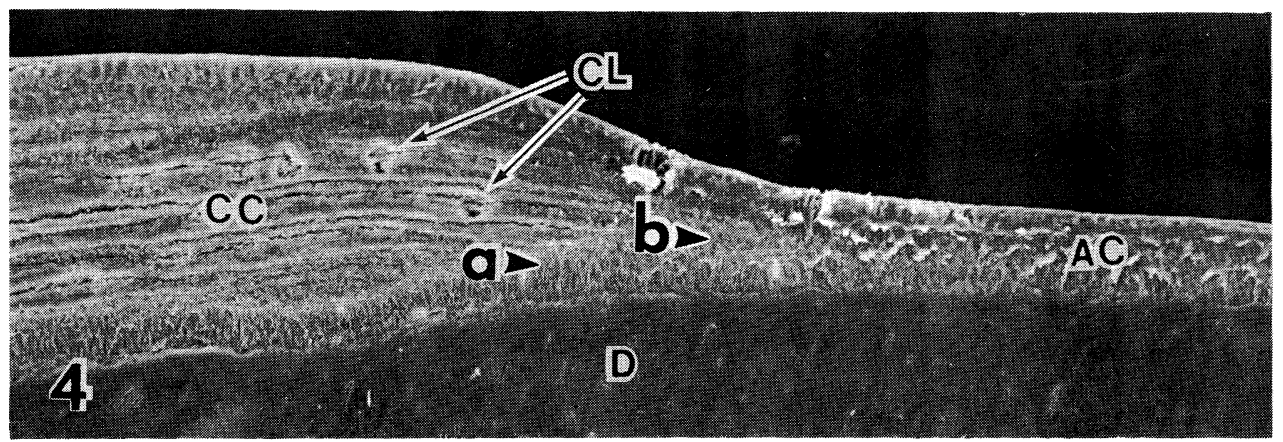

図 4 薄い無細胞セメント質 $(\mathrm{AC})$ と厚い有細胞セメント質 (CC)。研磨, 次亜塩素 酸 (60 分)一酸処理

厚い有細胞セメント質で溝に境された層構造が明瞭。CL：セメント小腔，D：象牙質。矢尻 $\mathrm{a}$, $\mathrm{b}$ は図 5 での拡大部分を示している。 $\times 140$
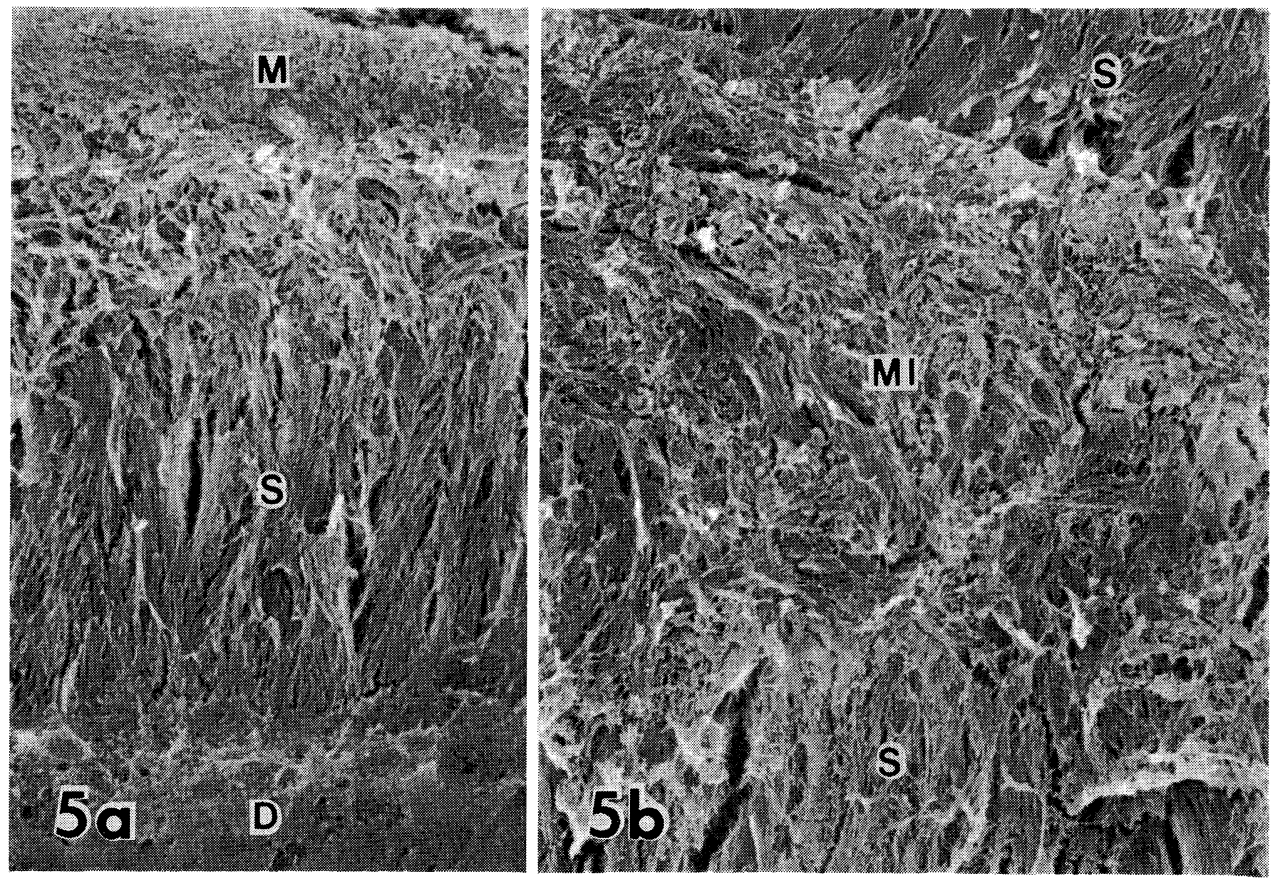

図 5 シャーピー線維層, 基質線維層, 混合線維層

a 図 4 の矢尻 $\mathrm{a}$ 部分の拡大像。シャーピー線維層 ( $\mathrm{S}$ ) と基質線維層 (M) の境界部では束の ほぐれたシャーピー線維の間に基質線維が混入している。 D : 象牙質。 $\times 1,300$

$\mathrm{b}$ 図 4 の矢尻 b 部分の拡大像。セメント質表層と深層のシャーピー線維 $(\mathrm{S}$ ) 層に挾まれた混 合線維層 (MI)。シャーピー線維束がほぐれて走行が乱れ，その間に基質線維が混入し，線 維配列が不規則である。 $\times 2,000$

滑でなく，これらの線維の相互の関係は不明瞭であっ た。

\section{2. 研磨面}

歯頸側の薄いセメント質では凍結割断面と同様に，セ メント質表面に垂直なシャーピー線維が密に配列してい
た。厚いセメント質でも，深側にシャーピー線維層が認 められた（図 $3 \mathrm{a}$ )。その外側の基質線維層では，基質線 維束が凍結割断面に比べ明瞭に観察された。線 維 束に は, 研磨面に垂直し歯を輪状に取り巻く線維束の横断 面, 歯軸方向に配列する線維束の縦断面が認められた 

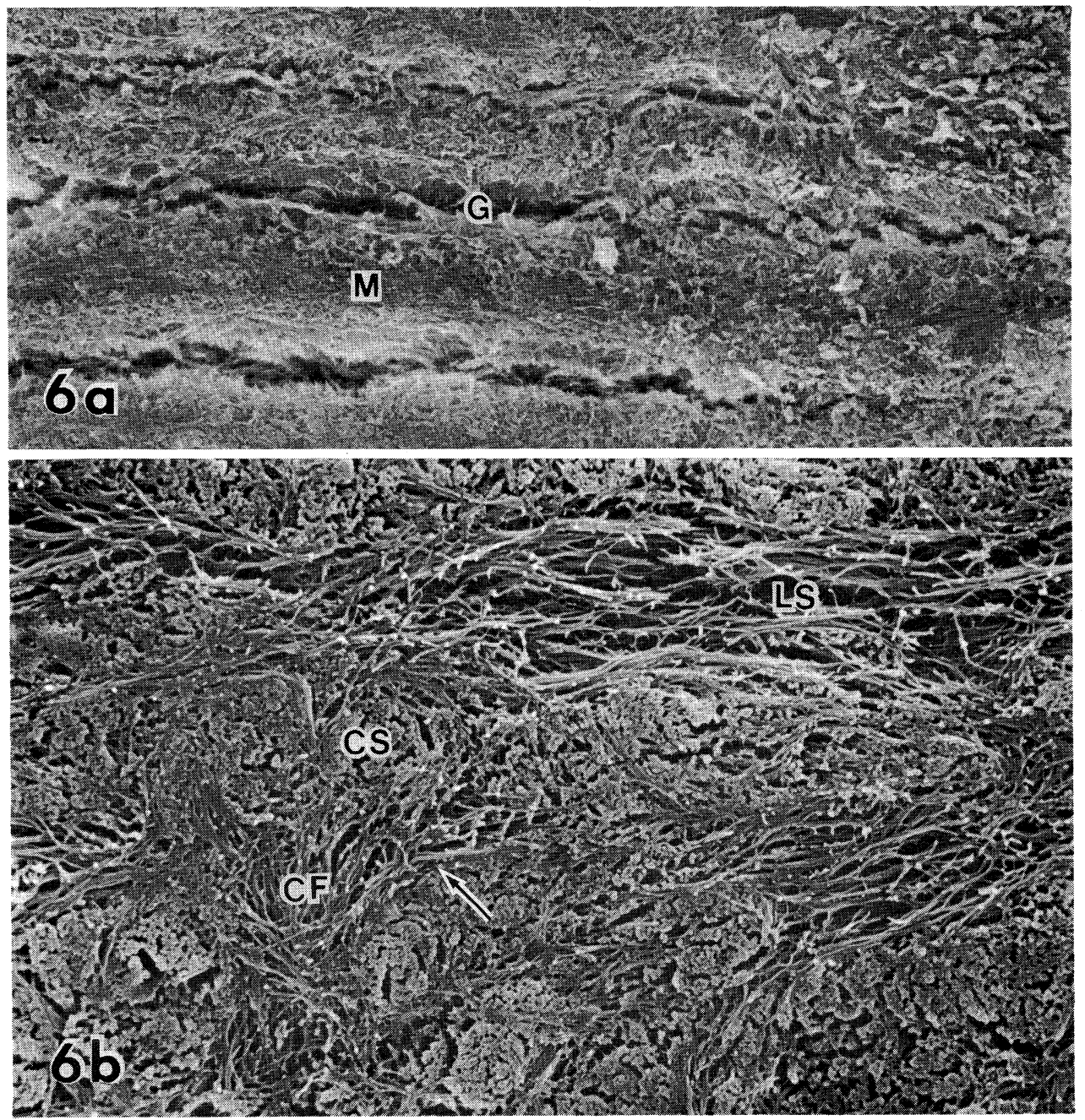

図 6 基質線維層。研磨, 次亜塩素酸一酸処理

a 各基質線維層 (M) は処理により生じた幅の狭い溝 $(\mathrm{G})$ に境されている。 $\times 1,300$

b 基質線維層の拡大像。酸処理のみに比べ, 線維の走行がより明瞭である。歯軸方向に走行す る基質線維束の縱断面 (LS)，歯を輪状に取り巻く基質線維束の横断面（CS）と，これらの 線維束の間にセメント質の深浅方向に走る短い交差線維 (CF) が認められる。また, 交差線 維の一部が歯軸方向に走行する線維と連絡している（矢印）。×6,600

(図 $3 \mathrm{~b}$ )。また, これらの線維束の間に, セメント質深部 から浅部方向に走行する短い交差線維 ${ }^{7)}$ が観察された。 交差線維の中にはその走行を変え, 歯軸方向の線維束に 移行する線維が認められた。

\section{3. 次亜塩素酸処理面}

凍結割断面と研磨面では，明瞭な層構造は観察されな かった。しかし，層構造を有するセメント質研磨面を 5 \%次亜塩素酸ナトリウム溶液で 60 分間処理し, さらに 0.5 1 M 塩酸で $30 \sim 60$ 秒間処理（次亜塩素酸一酸処
理) すると，層構造が観察された (図 4)。この層板は， 歯頸側の薄いシャーピー線維を主体とした無細胞セメン 卜質では観察されず，根尖側の厚いセメント質で認めら れた。層構造の数は, セメント質が厚くなると共に増加 した。層構造は，セメント質表面に平行して線維の溶出 した幅の狭い溝と, 溶出の少ない幅の広い板状構造で構 成されていた。

これらの試料で層構造と線維性基質の関係を観察し た。セメント質深部では凍結割断面・研磨面と同様に, 


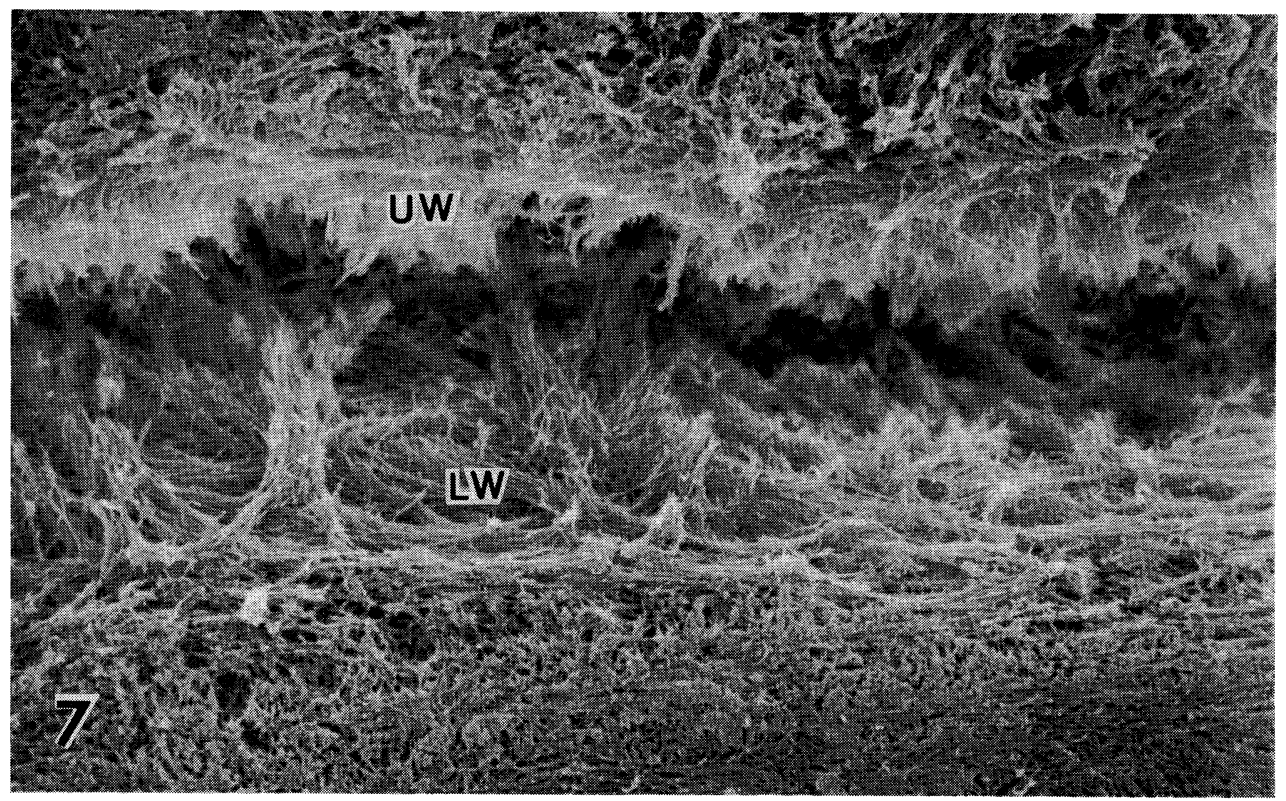

図 7 基質線維層を境する溝の拡大像。研磨，次亜塩素酸一酸処理

溝の上方のセメント質表面側の壁 (UW) では, 壁面から突出した短い線維束の断端が多数認め られる。溝の下方の象牙質側の壁（LW）は，壁の表面に沿った線維束に被われ，少量の線維束 が壁面から突き出している。 $\times 3,300$

最深部のシャーピー線維層と基質線維層が区別された (困 5 a)。シャーピー線維層は, 割断面や研磨面よりも明 瞭に識別できた。基質線維層とシャーピー線維層の境界 部では，シャーピー線維束はほぐれ，その間に基質線維 が混入し，移行部を形成していた。また，両線維成分が 混在する移行部が厚い層構造を示す部分（混合線維層） も認められた（図 $5 \mathrm{~b}$ )。混合線維層では，束がほぐれ走 行の乱れたシャーピー線維の間に基質線維が不規則に混 入するため，両線維成分の区別が困難な部分もあった。 深部の基質線維層の外側では，溝で境される基質線維層 が多数観察された（図 4,6 a)。溝で境される基質線維層 では，各層を構成する線維の配列や線維の溶出の程度に 差異が認められた。比較的溶出が少なく明膫な線維束を 有する部分では，凍結割断面や研磨面と同様に，歯を輪 状に取り巻く線維束の横断面，歯軸方向に配列する線維 束の縦断面と，これらの線維束と交差する短い交差線維 の縦断面が観察された (図 $6 \mathrm{~b}$ )。基質線維層の間で深い 溝を観察すると，溝の深側 (象牙質側) の壁面はその表 面に沿った線維束に被われ，壁面からセメント質表面へ 向い突き出した短い線維束の断端が一部に認められた。 溝の表面側 (セメント質表面側) では，壁面からセメン 卜質深部へ向う線維束の断端が深側に比べ多数観察され
た(図 7)。

次亜塩素酸で 120 分間処理寸ると 60 分間処理に比 べ 線維の溶出量が増加した（図 8)。60 分間処理ではあま り溶出しない基質線維層もその大部分が溶出した。その ため, 薄い板状構造と, それよりも幅の広い溶出部(溝) が交互に重り，層構造を形成していた。この板状構造 も，それぞれ溶出の程度が異なり，ほとんど溶出しない 丈の高い構造や，わずかに溶出せずに残った構造が認め られた。

\section{考察}

セメント質は, 一般にセメント細胞の有無により無細 胞セメント質と有細胞セメント質に分けられる。さらに セメント質は基質の線維の種類によって, 線維を含まな い無線維セメント質 (afibrillar cementum), 非固有線維 (シャーピー線維) のみを含む非固有線 維 セメント質 (extrinsic fiber cementum), 固有線維 (基質線維)のみ を含む固有線維セメント質 (intrinsic fiber cementum) と, 両線維成分を含む混合線維セメント質 (mixed fiber cementum）に分類されている ${ }^{14)}$ 。本研究ではこの分類 を基に，セメント質の層構造を形成する線維性基質によ 


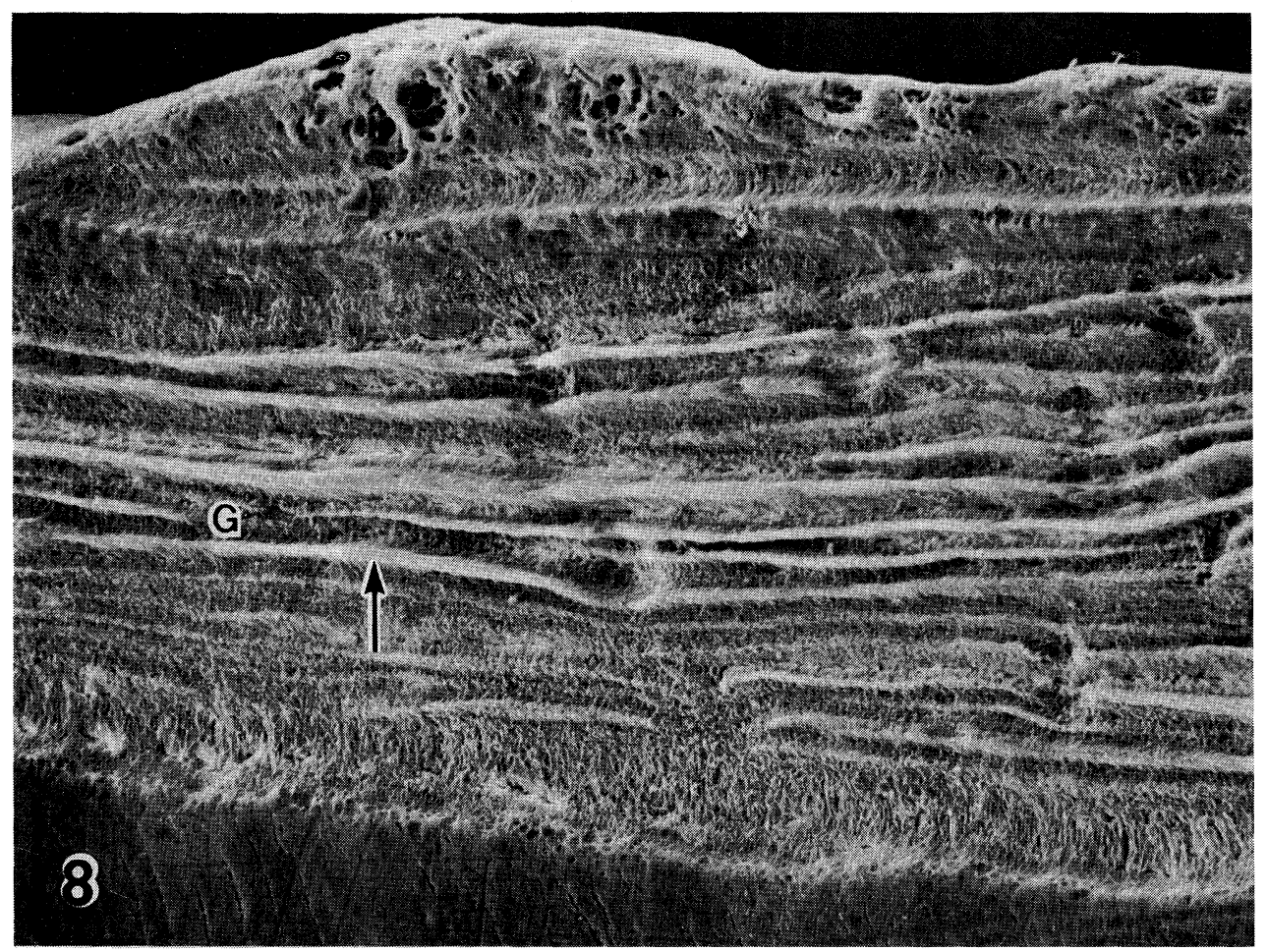

図 8 根尖側の厚い有細胞セメント質。研磨, 次亜塩素酸 (120 分)一酸処理

薄い板状構造 (矢印) と幅の広い溝 (G) が交互に重なる層構造が認められる。溝の深さや幅, 板状構造の厚さや高さは部位により異なる。D：象牙質。 $\times 260$

\section{り分類を試みた。}

歯頸側の薄い無細胞セメント質と, 根尖側の厚い有細 胞セメント質の最深部の, シャーピー線維が主成分であ る層をシャーピー線維層とした。シャーピー線維層で は, セメント一象牙境に垂直し互いに平行する線維束で 形成されていた。

層構造を有する厚い有細胞セメント質で, 基質線維が 主成分である層を基質線維層とした。基質線維層では, シャーピー線維に垂直な線維が, 複雑に交差して網状構 造を作っていた。しかし, 線維束が明瞭な部分では, 歯 軸方向に走行する基質線維束と, 歯を輪状に取り巻く基 質線維束が交互に重なっていた。また, これらの線維束 を結ぶように走行する短い交差線維 ${ }^{7)}$ が認められた。歯 の縦断 · 横断 · 接線方向の断面の透過型電子顕微鏡によ る観察で, 交差線維は歯軸方向と輪状方向の基質線維束 と連続し, 移行していることが報告されている7)。走査 型電子顕微鏡観察でも同様なことが認められた。これら のことから, 交差線維の多くは歯軸方向と輪状方向の基 質線維束を結ぶように配列した基質線維であると思われ
る。しかし，この交差線維については, さらに詳細に観 察し, 基質線維との関係とその配列の意義を明らかにす る必要がある。

基質線維層中には層板を貫く明瞭なシャーピー線維束 を認めなかった。シャーピー線維は歯を歯槽骨に固定す る機能を有して㧍り，基質線維層中にも存在していると 思われる。また，セメント質表面の走查型電子顕微鏡に よる観察では，根尖部の極く一部を除き，基質線維が多 量に存在する部分でも, 15〜 40\% がシャーピー線維であ るとされている10)。基質線維層には，シャーピー線維が 埋入されているが，少量であるために今回は観察されな かったと思われる。

シャーピー線維層と基質線維層の境の, 両線維成分が 入り乱れた層を混合線維層とした。混合線維層では, シ ヤーピー線維束がほぐれ，その間に基質線維が不規則に 混入するために，両線維成分の区別が困難な部分があっ た。この構造は, 両線維層の境界で観察された, 両線維 層の移行部と考えられる。

光学顕微鏡で観察されるセメント質の層構造は, 超微 
細構造レベルで同定するのが困難であるとされてい る15)。本研究においても，酸処理のみを施した割断面や 研磨面では, 光学顕微鏡で認められるような層構造は観 察されなかった。しかし，セメント質研磨面を次巠塩素 酸ナトリウム溶液 (次亜塩素酸) で 60 分閒処 理 し,さ らに塩酸で処理 (次亜塩素酸一酸処理) すると, 線維が 溶出して生じた溝に境される層構造が初めて認められ た。

次亜塩素酸は強力な脱有機作用を有し, 硬組織化付着 している軟組織や，その中の未石灰化部分の除去に用い られる ${ }^{10,16)}$ 。また，セメント質中のコラーグン線維は,

一本の線維でも石灰化の良い部分と悪い部分を有するこ とが透過型電子顕微鏡で報告されている7,17)。次鱼塩素 酸一酸処理により溶出する構造は, 研磨面に露出した線 維の未石灰化部分や低石灰化部分が次亜塩素酸により脱 有機され，さらに線維性基質を失った石灰化セメント質 が盐酸の脱灰作用により流れ出し生じると考えられる。

溝形成は，基質線維層間の境界面が溶出しやすい構造 であったことによると考えられる。この部分には線維性 基質の断層が有ったか，また石灰化が低いためと思われ る。深く溶出された溝の深側 (象牙質側) の壁面は比較 的平滑であるが，表面側（セメント質表面側）では壁面 から多数の線維束が突出していた。深側の壁面が平滑 で, 線維束がそのまま抜け落ちたように見えるのは, こ の部分に線維の不連続性があったことを示している。こ の溝には，周囲の線維と交差・連続が少ない，互に平行 する線維束が並んでいたと思われる。また，細胞セメン ト質中のシャーピー線維は, 周囲の基質線維よりも石灰 化が悪いとされている ${ }^{4,18)}$ 。表面側の壁面から突出した 線維束の存在と合せて考えると, この溝の部分には, 石 灰化の悪い短いシャーピー線維が多く存在していたとも 考えられる。

次亜塩素酸を 120 分間処理すると, 薄い板状構造を残 してセメント質の大部分が溶出した。この板状構造は, 石灰化の良い基質線維が網状構造を形成しているために 残ったと考えられる。マイクロラジオグラムによる観察 では, 細胞セメント質中にセメント質表面と平行な, 高 度に石灰化した層構造が認められている。これは高石灰 化層で, 成長線に相当することが示されている ${ }^{18)}$ 。 120 分間処理で溶出せずに残る薄い板状構造は, この高度に 石灰化した層で, 光学顕微鏡で認められる成長線に相当 すると思われる。溝構造の形成はすでに説明したよう に, 基質線維の断層に成長線の外側で新たなセメント質 の添加が急速に始った部位に形成されると考えられる。
そのため, 溝構造は成長線（休止線）の外側の線維性基 質の不連続部に出現すると思われる。

しかし, 次带塩素酸一酸処理により層構造の生じる理 由は, 層構造の石灰化度の差異だけで説明できず, 溶出 するセメント質の線維組成と線維配列も関係している。 今後, 処理により線維が溶出される過程を検討し, 光学 顕微鏡で認められる層構造との対比を行うことで, 層構 造と線維性基質の関係をさらに明らかにできると思われ る。また, 根面処理や線維性付着を考える上でも, セメ ント質の線維性基質と層板構造を明らかにすることは有 意義と思われる。

\section{結論}

ヒトの歯のセメント質の層板構造と線維性基質の関倸 を明らかにするために，セメント質断面を酸などで処理 し走查型電子顕微鏡で観察し, 以下の結果を得た。

1. 酸処理のみを施した凍結割断面と研磨面では, シ ヤーピー線維を主体とした部分と基質線維を主体とした 部分を区別できた。しかし, 光学顕微鏡で認められるよ らな層構造は観察されなかった。

2. 研磨面を次亜塩素酸ナトリウム溶液で 60 分間処 理し, さらに塩酸で処理した。すると, セメント質表面 と平行な, 線維が溶出して生じた幅の狭い溝と, 溶出さ れにくい幅の広い部分による層構造が初めて出現した。

3. 層構造はその線維性基質により, シャーピー線維 が主成分のシャーピー線維層, 基質線維が主成分の基質 線維層, 両線維成分が混在する混合線維層に分けること ができた。

4. 次亜塩素酸で 120 分間処理すると, 60 分間処理で は溶出せずに残った基質線維層の殆どが溶出し, 薄い板 状構造が残った。この構造は石灰化度の高い成長線（休 止線）に相当し，その両側には線維性基質と石灰化度に おいて不連続があることが示唆された。

\section{文献}

1) Gerould, C.H. : Ultramicrostructures of the human tooth as revealed by the electron microscpe. J. Dent. Res., $23: 239-245,1944$.

2) Awazawa, Y. : Electron microscopy of human cementum. J. Nihon Univ. Sch. Dent., $5: 127-$ 137, 1963.

3) Stern, I.B. : An electron microscopic study of 
the cementum, Sharpey's fibers and periodontal ligament in the rat incisor. Am. J. Anat. 155 : 377-410, 1964.

4) Selvig, K.A. : The fine structure of human cementum. Acta Odont. Scand., $23: 423-441$, 1965.

5) Furseth, R. : The fine structure of acellular cementum in young human premolars. Scand. J. Dent. Res., 82 : 437-441, 1974.

6) Furseth, R. : The fine structure of the cellular cementum of young human teeth. Archs. Oral Biol., 14 : 1147-1158, 1969.

7）陳 妙卿：ヒトセメント質における基質線維の基 本構造に関する観察. 口病誌, $54: 635-675,1987$.

8) Boyde, A. and Jones, S.J. : Scanning electron microscopy of cementum and Sharpey fibre bone. Z. Zellforsch. Mikrosk. Anat., 92 : 536$548,1968$.

9）徳永純一, 森 淑子 : 走査電子顕微鏡による人歯 セメント質表面の微細構造. 歯基礎誌, 11 : 1323, 1969.

10) Jones, S.J. and Boyde, A. : A study of human root cementum surfaces as prepared for and examined in the scanning electron microscope. Z. Zellforsch. Mikrosk. Anat., $130: 318-337$, 1972.

連絡先 :

東日本学園大学歯学部口腔解剖学第一講座

干 061-02 北海道石狩郡当別町字金沢 1757
11）鰺坂正彦 : 走査型電子鏡によるカイウサギのセメ ント質の観察. 日大歯学, $47: 382-388,1973$.

12）小林 譲 : 走査型電子鏡によるヒトの歯のセメン 卜小腔の観察. 日大歯学, $50: 31-34,1976$.

13) Ismail, O.S. and Weber, D.F. : Light and scanning electron microscopic obervations of the canalicular system in human cellular cementum. Anat. Rec., 222 : 121-127, 1988.

14) Jones, S.J. : Cement, Osborn, J.W., Dental anatomy and embryology, Blackwell Scientific Publications, Oxford, 1981, 193-205.

15) Armitage, G.C. : Cementum, Bhaskar, S.N., Orban's oral histology and embryology, 9 th edn., Mosby, St. Louis, 1980, 180-203.

16）水城晴美 : ヒト下顎歯槽骨内壁における線維骨の 構造に関する組織学的観察. 口病誌, $46: 65-104$, 1979.

17) Matthiessen, M.E., Sögaard-Pedersen, B. and Römert, P. : Electron microscopic demonstration of non-mineralized and hypomineralized areas in dentin and cemenutm by silver methenamine staining of collagen. Scand. J. Dent. Res., 93 : 385-395, 1985.

18）藤井仁毅：セメント質の石灰化像. 歯学, 57 : 206-228, 1969. 